\title{
Genetic Variation in Frost Damage and Seed Zone Delineation within an Altitudinal Transect of Pinus devoniana (P. michoacana) in Mexico
}

\author{
By C. SÁenz-Romero ${ }^{1)}$ and B. L. Tapia-Olivares
}

\author{
Instituto de Investigaciones Agropecuarias y Forestales, \\ Universidad Michoacana de San Nicolás de Hidalgo (IIAF-UMSNH) \\ Km 9.5 Carr. Morelia-Zinapecuaro, Tarimbaro Michoacan 58880, Mexico
}

(Received $18^{\text {th }}$ January 2007)

\begin{abstract}
We explored the patterning of genetic variation among Pinus devoniana Lindl. (also known as P. michoacana Martínez) populations to develop guidelines for seed and seedling movements, intended for improving the matching between genotypes and environments regarding frost tolerance, in reforestation programs. Open-pollinated seed from 16 populations along an altitudinal transect (1600 to $2450 \mathrm{~m}$ ) were collected near Morelia, State of Michoacán, México. A common-garden provenance test, established with 2.5-year-old seedlings, was assessed for frost resistance conducting a laboratory frost damage test $\left(-9^{\circ} \mathrm{C}\right)$. Results indicate that there were significant differences among provenances $(\mathrm{P}=0.0261)$ for frost damage. Variation among provenances was structured as an altitudinal cline, with populations from lower altitudes being the least tolerant to frost. Linear regression statistics suggest that for each increment of $100 \mathrm{~m}$ of provenance altitude, there will be a $5.2 \%$ decrease in frost damage. We suggest the use of two provisional altitudinal seed zones of $400 \mathrm{~m}$ breadth each (lower and upper limits for zone 1:1600 m and $2000 \mathrm{~m}$ of altitude; for zone 2: 2000 and $2400 \mathrm{~m}$, respectively), and for reforestation of a given site, the use of seedlings originated from seed of the same seed zone or within $\pm 200 \mathrm{~m}$ of altitude from the elevation of the reforestation site.
\end{abstract}

Key words: Pinus devoniana, Pinus michoacana, altitudinal genetic variation, provenances, frost damage, frost hardiness, seed zoning, seed and seedling movement guidelines.

\section{Introduction}

Frost damage is one of the main causes of poor growth and mortality of seedlings in reforestations using pine species in México (BELlo-LARA and CIBRIÁN-TovAR, 2000; SÁENZ-ROMERO et al., 2003). Frost damage accounts for the $14 \%$ of mortality in reforestations in the Mexican western State of Michoacán (SÁENZ-ROMERo and LINDIGCisneros, 2004). Frost damage also causes reduced growth and poor stem form (ANEKONDA and ADAMS, 2000). Occurrence of frost damage in provenance tests or field plantings is an indication of lack of compatibility between the genotype of the tree and the climate of the planting site (development is out of phase with the environment). Thus, prevention of frost damage requires better matching between genotypes and environments.

Studies on conifer species in the Rocky Mountains have shown that populations are genetically differenti1) Corresponding author: Phone/Fax +(52)(443) 295-8323 and
295-8324. E-mail: csaenz@umich.mx. ated along altitudinal gradients, with populations from lower altitudes having less frost hardiness than populations from higher altitudes (CAMPBELL, 1979; REHFELDT, $1985,1988,1989,1991)$. It is expected that such patterns will occur in Mexican pines distributed along mountain systems. However, such patterns are generally unknown for Mexican pines. In order to appropriately match seedling genotypes (regarding frost hardiness) and environmental conditions of the sites to be reforested, and thus to increase survival and seedling growth in the reforestation zones, one needs to know the patterning of genetic variation among populations along altitudinal gradients for Mexican pine species. If such pattern is known, then it is possible to delineate seed zones, as guidelines for deciding seed and seedling movements within and among regions in reforestation programs, and thus to improve the matching between genotypes and environments (REHFELDT, 1983a, 1983b; SÁENZRomero, 2004a; SÁenz-Romero, 2004b; SÁenz-Romero et al., 2006). At present, the patterns of variation in $P$. devoniana are not known and empirically based seed zones do not exist in Mexico.

There is evidence of correlation between seedling response to artificially-induced frost damage in laboratory conditions and seedling response to frost damage in field conditions, with an average genetic correlation of 0.85 (AitKen and AdAMs, 1997; O’Neill, 1999). Also, there are strong correlations $\left(\mathrm{r}^{2}>0.90\right)$ between results using visual injury scoring (a technique with an unavoidable component of subjectivity) and results using more objective techniques for injury assessments, such as electrolytic conductivity (SHORTT et al., 1996) or chlorophyll fluorescence (BINDER et al., 1997).

Pinus devoniana Lindley (also known as Pinus michoacana Martínez) has a natural distribution confined mostly to México (the states of Nayarit, Zacatecas, Jalisco, Colima, Michoacán, Hidalgo, Mexico, Puebla, Morelos, Guanajuato, Tlaxcala, Guerrero, Oaxaca, Veracruz, and Chiapas), and in Guatemala (the departments of Totonicapán, Quiche, Quetzaltenango, Chimaltenango, Sacatepequez, and Guatemala), in pine-oak and pine forest, in pure stands or mixed with Pinus montezumae, P. pseudostrobus and P. oocarpa (PERRY, 1991; FARJON and STYLES, 1997). Near Morelia, capital of the State of Michoacán, western México, the species occurs between $1600 \mathrm{~m}$ to $2450 \mathrm{~m}$ of altitude on the Neovolcanic Axis slopes, mixing with $P$. oocarpa at the lower limit of the altitudinal distribution and with $P$. pseudostrobus at the higher altitudes. 
P. devoniana is widely used in Mexico for sawtimber, paper pulp and resin production. In the State of Michoacán in particular, the species is important for the local Native Indian handcraft industries, such as rustic furniture, marquetry and guitar parts (MUSÁLEM and SÁNCHEZ-CRUZ, 2003). Thus, success of $P$. devoniana plantations is very important not only for ecological restoration purposes, but also for the local economy, particularly that of the most impoverished segment of Mexican society, the Native Indians.

The goals of the present study are: a) to explore the patterning of genetic variation among $P$. devoniana populations along an altitudinal gradient, using provenance common garden tests and lab frost damage tests, and b) to delineate altitudinal seed zones as guidelines for controlling seed and seedling movement in reforestation.

\section{Materials and Methods}

Open pollinated seeds were collected from five to 10 trees (randomly selected among those trees bearing cones) from each of 16 natural $P$. devoniana populations. Collection was made along an altitudinal transect, from San Miguel del Monte (2450 m of altitude) to near Tumbisca village (1600 $\mathrm{m}$ of altitude), near Morelia, in the Mexican western State of Michoacán (Figure 1). The sampled populations were located approximately at every $50 \mathrm{~m}$ of altitudinal difference (Table 1). Sites at 1900 and $2000 \mathrm{~m}$ of elevation were not included because a low stand density made the sampling of at least 5 trees impossible. The trees represented by the samples are termed populations, whereas the location of a population is called provenance.
Seedlings were grown in $380 \mathrm{~cm}^{3}$ Broadway Plastics de México ${ }^{\circledR}$ containers on commercial Creciroot $^{\circledR}$ substrate. When the seedlings were 7 months old, they were transplanted to a rectangular wooden-structure raised bed, filled with a $40 \mathrm{~cm}$ - layer of $4: 1 \mathrm{mix}$ of Creciroot $^{\circledR}$ substrate and local Andosol forest soil, placed over a $20 \mathrm{~cm}$ layer of extrusive volcanic small stones for improving drainage. The raised bed was built inside a shade house (35\% shade) where a common garden test was established. The experimental design was randomized complete blocks, with five blocks, 16 provenances and six seedlings per plot in a row. Seedlings were spaced at $15 \mathrm{~cm}$ within plots and $15 \mathrm{~cm}$ among plots. The first and last plots were flanked by a protection row from randomly chosen seedlings. Both nursery and raised bed experiments were located at the Instituto de Investigaciones Agropecuarias y Forestales, Michoacan University, near Morelia, Michoacán, México (1830 $\mathrm{m}$ of altitude, $19^{\circ} 42^{\prime} \mathrm{LN}, 101^{\circ} 11^{\prime} \mathrm{LW}$, annual mean temperature $17.5^{\circ} \mathrm{C}$, annual mean precipitation $776 \mathrm{~mm}$, GARCIA, 1988). Seedlings were watered as needed.

An artificially-induced frost damage test, using visual injury scoring on needle tissue, was conducted in the laboratory. The technique was developed based on REHFELDT (1980, 1985). The test was conducted at a seedling age of 2.5 years (almost two years on the raised bed) which meant that the grass stage had been passed. The freezing treatments were conducted in December and January while the seedlings were in the winter rest stage. Three healthy fascicles located $5 \mathrm{~cm}$ below the bud were removed from each seedling in the morning following a day of irrigation. The seedlings, therefore,
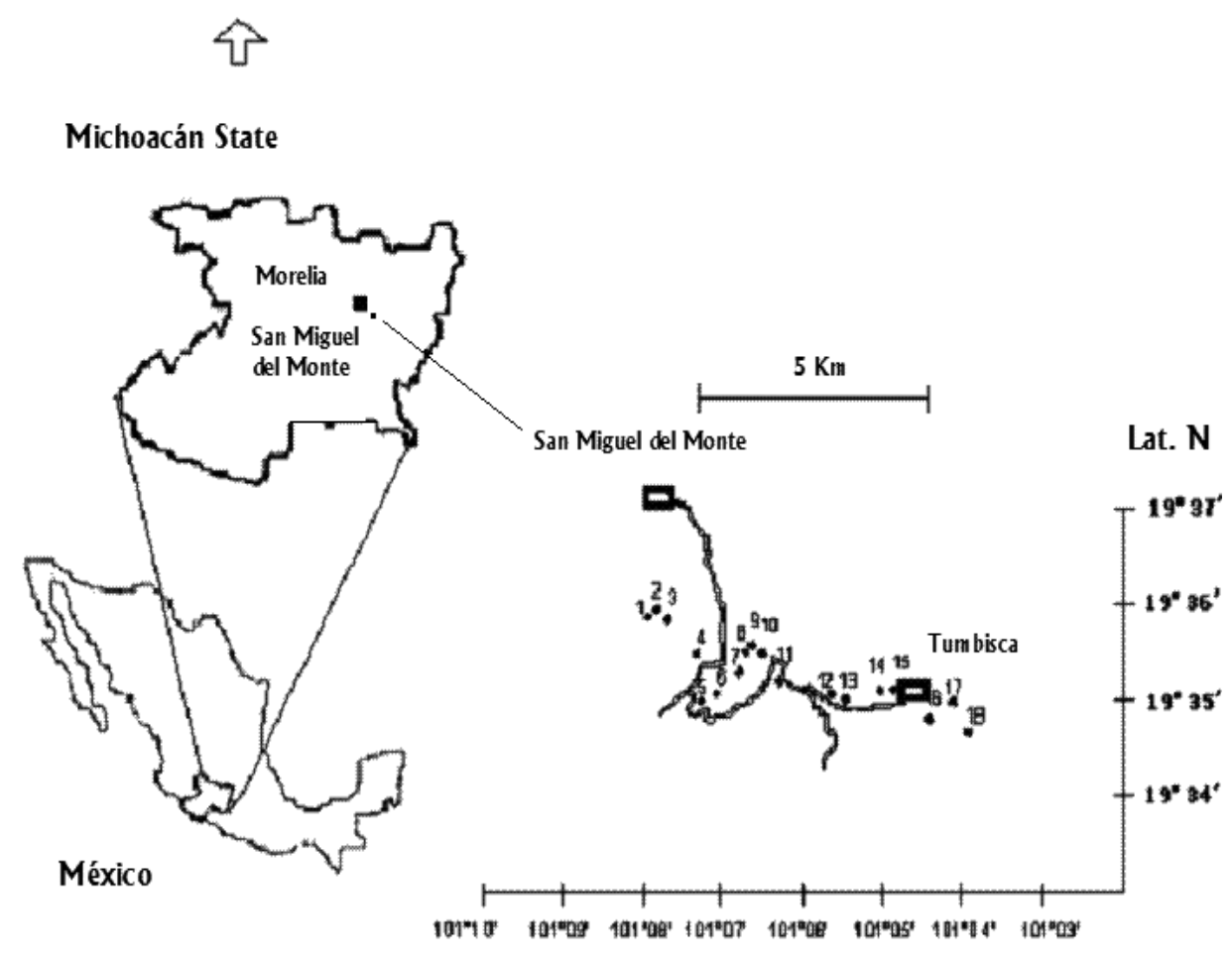

Long. W

Figure 1. - Location of sixteen Pinus devoniana populations (Number codes keyed to Table 1) sampled along an altitudinal transect near Morelia, State of Michoacán, western México. 
Table 1. - Location of sixteen Pinus devoniana populations sampled along an altitudinal transect in the region of Morelia, State of Michoacán, western México.

\begin{tabular}{|c|c|c|c|c|c|}
\hline Num. & Altitude (m) & Iocality & Site & [atitude & Longitude \\
\hline 1 & 2450 & SMM & Peña de San Pedro & $19^{\circ} 35^{\prime} 52.10^{\prime \prime}$ & $101^{\circ} 0755.5^{\prime \prime}$ \\
\hline 2 & 2400 & SMM & Pentas de San Pedro & $19^{9} 3555.70^{\prime \prime}$ & $101^{\circ} 0752.10^{\prime \prime}$ \\
\hline 3 & 2350 & SMM & La Lobera & $19^{\circ} 35^{\prime} 50.40^{\prime \prime}$ & $101^{\circ} 0741.60^{\prime \prime}$ \\
\hline 4 & 2300 & SMM & La Virgeneita & $19^{\circ} 35^{\prime} 29.00^{\prime \prime}$ & $101^{\circ} 07^{\prime \prime} 18.70^{\prime \prime}$ \\
\hline 5 & 2250 & RTS & Banco de balastre & $19^{\circ} 34^{\prime} 57.40^{\prime \prime}$ & $101^{\circ} 07^{\prime} 17.80^{\prime \prime}$ \\
\hline 6 & 2200 & RTS & Banco de balastre & $19^{\circ} 35^{\prime} 04.70^{\prime \prime}$ & $101^{\circ} 0703.90^{\prime \prime}$ \\
\hline 7 & 2150 & RTS & Loma del Patio & $19^{\circ} 35^{\prime} 17.30^{\prime \prime}$ & $10]^{\circ} 06^{\prime} 48.10^{14}$ \\
\hline 8 & 2100 & RTS & Loma del Patio & $19^{\circ} 35^{\prime} 30.30^{\prime \prime}$ & $101^{\circ} 06^{\prime} 42.70^{\prime \prime}$ \\
\hline 9 & 2050 & RTS & La Cruz & $19^{\circ} 35^{\prime} 34.80^{\prime \prime}$ & $10]^{\circ} 06^{\prime} 38.10^{\prime \prime}$ \\
\hline 11 & 1950 & RTS & FI Asertadero & $19^{\circ} 35^{\prime} 12.30^{\prime \prime}$ & $101^{\circ} 06^{\prime} 17.70^{\prime \prime}$ \\
\hline 13 & 1850 & Tumbisca & El Cuilito & $19^{\circ} 35^{\prime} 00.90^{\prime \prime}$ & $101^{\circ} 05^{\prime} 26.80^{\prime \prime}$ \\
\hline 14 & 1800 & Tumbisca & El Puertccito & $19^{\circ} 35^{\prime} 05.90^{\prime \prime}$ & $101^{\circ} 05^{\prime} 02.60^{\prime \prime}$ \\
\hline 15 & 1750 & Tumbisea & Cerrito Márquez & $19^{\circ} 35^{\prime} 05.70^{\prime \prime}$ & $101^{\circ} 04^{\prime} 48.20^{\prime \prime}$ \\
\hline 16 & 1700 & Turribisca & El Reparo & $19^{\circ} 34^{\prime} 48.30^{\prime \prime}$ & $101^{\circ} 04^{\prime} 24.30^{\prime \prime}$ \\
\hline 17 & 1650 & Tumbisea & El Tularcillo & $19^{\circ} 34^{\prime} 58.70^{11}$ & $10]^{\circ} 04^{1} 06.20^{14}$ \\
\hline 18 & 1600 & Tumbisca & El Tularcillo & $19^{\circ} 34^{\prime} 40.0^{\mathrm{m}}$ & $101^{\circ} 03^{\prime} 55.2^{\prime \prime}$ \\
\hline
\end{tabular}

SMM = San Miguel del Monte, RTS = Road Tumbisca - San Miguel del Monte.

were free of draught stress. Fascicles were sealed in plastic bags and stored in a refrigerator at $7^{\circ} \mathrm{C}$ for 12 hours. Then, samples were placed inside a cardboard box in a freezer set at $1^{\circ} \mathrm{C}$; a thermistor was placed inside the box. Space limitations required that treatments were run separately for each block. When the samples reached $1^{\circ} \mathrm{C}$, the temperature was slowly decreased at a rate of $2^{\circ} \mathrm{C} /$ hour, until a target freezing temperature of $-9^{\circ} \mathrm{C}$ was reached. The target temperature was previously determined from the results of pilot tests, selected with the goal of achieving 30 to $70 \%$ damage (ANEKODA and ADAMS, 2000), too low a temperature caused close to $100 \%$ damage on all samples, whereas too mild temperatures did not cause damage. After reaching $-9^{\circ} \mathrm{C}$, the temperature was slowly increased at approximately the same rate $\left(2^{\circ} \mathrm{C} /\right.$ hour $)$, until reaching $0^{\circ} \mathrm{C}$. The samples were then thawed slowly by allowing the freezer to return to room temperature. The fascicles were then set out on a lab bench for 72 hours at room temperature, to allow cold injury symptoms to develop. Damaged tissues turned from green to brown, depending on the damage intensity. Damage was scored using a 0 to $100 \%$ score, were $0 \%$ was no damaged fascicles (intense green color, turgent, flexible), $100 \%$ was seriously damaged fascicles (brown color, dehydrated nee- dles, easily forming kinks when bending), and intermediate damage had intermediate values $(10 \%, 20 \% \ldots$ to $90 \%$ ). To minimize bias, all assessments were made by the same scorer.

Data were transformed to the arcsine of the square root of frost damage proportion to each seedling. Statistical analyses included analysis of variance to test significance among populations using PROC GLM of SAS (SAS, 1988). Percent of contribution of variance component to total variance was estimated using PROC VARCOMP METHOD = REML (SAS, 1988). These analyses used the following statistical model:

$$
\mathrm{Y}_{i j k}=\mu+\mathrm{B}_{i}+\mathrm{P}_{j}+\mathrm{B}_{i} \mathrm{x}_{j}+\varepsilon_{i j k}
$$

where $\mathrm{Y}_{i j k}=$ observation on the $k^{\text {th }}$ seedling of the $j^{\text {th }}$ population in the $i^{\text {th }}$ block, $\mu=$ overall mean, $\mathrm{B}_{i}=$ effect of the ith block, $\mathrm{P}_{j}=$ effect of $j^{\text {th }}$ population, $\mathrm{B}_{i} \times \mathrm{P}_{j}=$ interaction of block by population, and $\varepsilon_{i j k}=$ error term, $i=1, \ldots b, j=1, \ldots p$, and $k=1, \ldots n$, where $b=5, p=16$, and $n=6$, which are the numbers of blocks, populations, and seedlings-per-plot, respectively, not considering mortality. Blocks and populations were considered as random effects, from which inferences were to be made about the species as a whole. 
The relationship of genetic variation among populations to the altitude of the provenance was assessed with a linear model, using PROC REG (SAS, 1988). The model was:

$$
\mathrm{Y}_{i j}=\beta_{0}+\beta_{1} \mathrm{X}_{i}+\varepsilon_{i j}
$$

where $\mathrm{Y}_{i j}=$ population mean of frost damage, $\beta_{0}=$ intercept, $\beta_{1}=$ regression parameter, $\mathrm{X}_{i}=\operatorname{altitude}(\mathrm{m})$ of $i^{\text {th }}$ population origin, $\varepsilon_{i j}=$ error.

The least significant difference (LSD, $\alpha=0.20$ ) multiple mean comparison was conducted to estimate the altitudinal interval that must separate populations before one can be reasonably certain of genetic differentiation (REHFELDT, 1991).

Analysis of original and transformed data (arcsine of square root) gave essentially the same results; thus, results from regression analysis are presented using untransformed data, which is clearer for interpretation.

\section{Results and Discussion}

\section{Genetic differences among provenances}

There were significant differences among provenances for frost damage $(\mathrm{P}=0.0261)$ that accounted for $8 \%$ of

Table 2. - Analysis of variance for frost damage of sixteen $P$. devoniana provenances.

\begin{tabular}{lrrlc}
\multicolumn{1}{c}{ S.V. } & d.f. & \multicolumn{1}{c}{$\%$ F } & F & P \\
Block & 4 & 8.77 & 5.69 & 0.0006 \\
Provenance & 15 & 7.92 & 2.05 & 0.0261 \\
Blo * Prov & 56 & 13.16 & 1.84 & 0.0009 \\
Error & 254 & 70.16 & &
\end{tabular}

* Percentage of contribution of variance component to total variance. the total variance (Table 2). Differences among provenances are structured as an altitudinal cline along which populations from lower altitude had more frost damage than populations from higher altitudes $\left(\mathrm{r}^{2}=0.8046, \mathrm{P}=0.0001\right.$, Figure 2$)$.

The altitudinal cline of genetic variation among populations suggests that incidence of temperatures below zero along the $P$. devoniana altitudinal distribution has acted as a selective force resulting in genetic differentiation of populations; populations from lower altitudes are less tolerant to freezing temperatures than populations from higher altitudes. That trend is similar to what has been demonstrated for Pinus contorta (REHFELDT, 1985, 1988), for Pseudostsuga menziesii var. glauca (REHFELDT, 1989) in the Rocky Mountains and for Pseudostsuga menziesii var. glauca in western Oregon and Washington (STCLAIR, 2006). For the latest, genetic differentiation among populations is more pronounced for cold hardiness than for other traits, such as bud burst, bud set and 2-year-old biomass; also fall cold hardiness is strongly correlated to cold season temperatures of the source environment (STCLAIR, 2006).

The slope of the regression line $\left(\beta_{1}=-0.05161\right)$ estimates the change in freezing damage along the altitudinal gradient. Thus, for our test, a freezing temperature of $-9^{\circ} \mathrm{C}$ would cause a decrease in injury of $5.2 \%$ for each increase of $100 \mathrm{~m}$ of provenance altitude, and for each decrease of $100 \mathrm{~m}$ of provenance altitude, there should be an increase of $5.2 \%$ of frost damage. Consequently, a population originated at $2000 \mathrm{~m}$ of altitude should have $20.8 \%$ more frost damage than a population originated at $2400 \mathrm{~m}$.

The relationship between altitude and amount of frost damage also illustrates the amount of damage that can be avoided if the right provenance is chosen for a given reforestation site, and conversely, the amount of damage that will possibly occur when a wrong provenance is chosen. For example, if a site at the upper altitudinal limit $(2450 \mathrm{~m})$ of the $P$. devoniana natural distribution in the area is reforested using seed from the lowest altitudinal

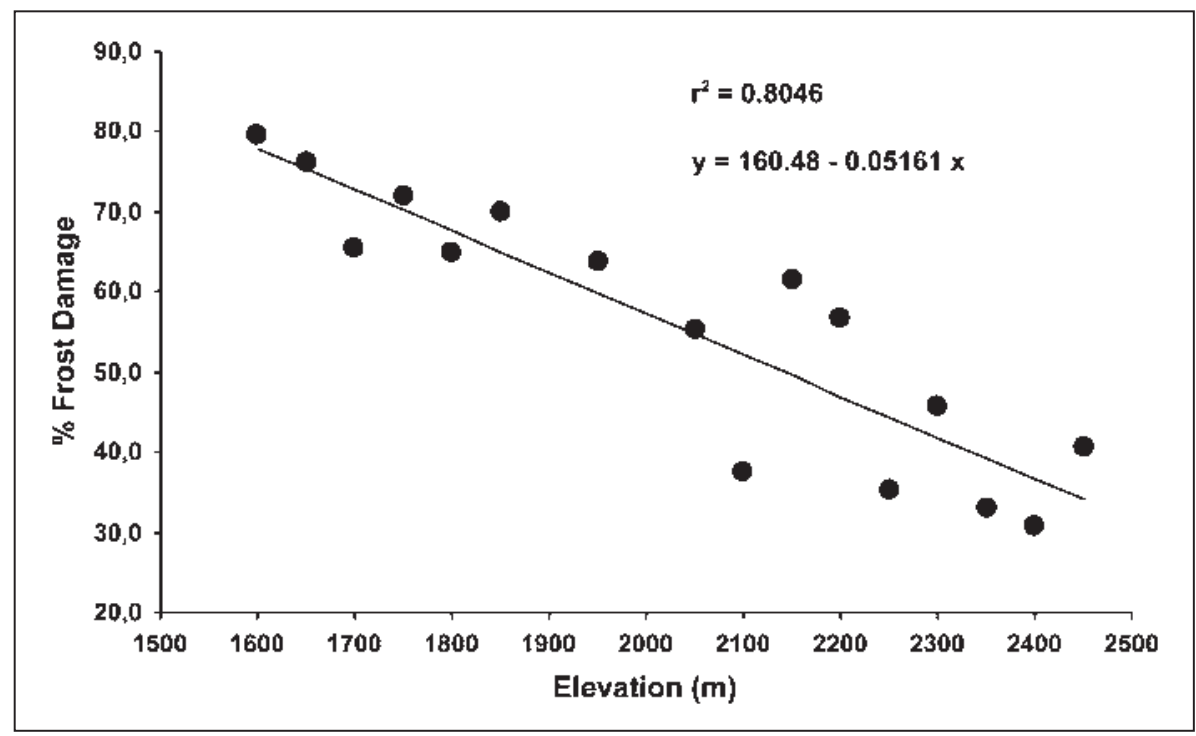

Figure 2. - Linear regression of population average percentage of frost damage with respect to elevation of origin of provenance. 
Table 3. - Simplified limits, ranges, and intervals of two altitudinal Pinus devoniana seed zones.

\begin{tabular}{ccccc}
\hline Seed zone & Limits (m) & Range & Interval $(\rightarrow)$ \\
& Lower & Upper \\
1 & 1600 & 2000 & 400 & 200 \\
2 & 2000 & 2400 & 400 & 200
\end{tabular}

limit $(1600 \mathrm{~m})$ of the distribution, there will be an unnecessary $44.2 \%$ greater frost damage than that on seedlings originated from local seed would be, if a temperature of about -9 was reached during the winter dormant period.

However, it remains to be seen, what the compromise between frost damage and growth potential might be. It is known that populations from lower altitudes have more growth potential than populations from higher altitudes (REHFELDT, 1988, 1991; SÁENZ-ROMERO et al., 2006), and trees with more growth potential appeared to be more susceptible to cold injury (AITEKEN et al., 1996). Consequently, there tends to be a negative relationship between growth potential and freezing tolerance.

\section{Altitudinal seed zoning}

The least significant difference (LSD, $\alpha=0.20$ ) between two populations was $19.99 \%$ of frost damage. The LSD ratio with respect to the regression coefficient suggests that populations separated by as little as 387 $\mathrm{m}$ are likely to be genetically different. Considering that the maximum altitudinal interval of $P$. devoniana natural distribution in the studied region is of $850 \mathrm{~m}$ of altitudinal difference (from 1600 to $2450 \mathrm{~m}$ ), two seed zones would cover almost all the interval of the natural distribution. Rounding up the LSD to $400 \mathrm{~m}$ of altitudinal difference, the altitudinal seed zones for $P$. devoniana in the Morelia region can be simplified and defined as in Table 3, delimitation starting at $1600 \mathrm{~m}$ of altitude. Notice that an alternative criterion is to use altitudinal intervals of $\pm 200 \mathrm{~m}$.

Suitable guidelines for ecological restoration would be: (a) For reforestation of a given seed zone, using seedlings originated from the same seed zone, and alternatively (b) for reforestation of a site at a given altitude, using seedlings originated from seed collected from $\pm 200 \mathrm{~m}$ of altitude regarding the elevation of the reforestation site.

These practical guidelines should be viewed as provisional. Future analyses will consider population growth potential and will assess the importance of compromises between frost resistance and growth potential in limiting seed transfer. Field data from tests located at different altitudes and on different regions of the species natural distribution range would be of particular value.

Extrapolation of the use of suggested altitudinal intervals of $\pm 200 \mathrm{~m}$ for moving seeds and seedlings in other regions, where $P$. devoniana is distributed, is suggested with caution (although altitudinal value of upper and lower boundaries might shift). This is a reasonable man- agement suggestion for the time while new data from provenance tests, eventually placed and evaluated in different regions, are available. Considering that altitude is a surrogate variable for temperature gradients (ROSENBERB, 1974) not only in Michoacán but anywhere in the species range, it is expected that limiting the altitudinal transfer of seed and seedling movement of $P$. devoniana to $\pm 200 \mathrm{~m}$ from the location of the seed collection to the reforestation site, will improve the matching between genotypes and environments.

Ideally, in the future, altitude limits of suggested seed zones need to be translated to climate variables, such as temperature, precipitation, degree days and annual moisture index (relationship between degree days and precipitation; see SÁENZ-Romero et al., 2006). However, that requires availability of enough weather data, something difficult to obtain in México and Guatemala. In any case, although provisional, the practical use of the current results is highly recommended, largely because no guidelines currently exist for this species in México.

\section{Conclusions}

Significant differences among provenances were detected for freezing injury. Genetic differences formed an altitudinal cline of decreasing injury with increasing altitude of the provenance. At a given freezing temperature $\left(-9^{\circ} \mathrm{C}\right)$, for each increase or decrease of $100 \mathrm{~m}$ of altitude of the provenance, there should be a $5.2 \%$ decrease or increase in frost damage, respectively.

We suggest to split the altitudinal distribution of $P$. devoniana into two altitudinal seed zones of $400 \mathrm{~m}$ breadth (starting at $1600 \mathrm{~m}$ of altitude), and for reforestation of a given site to use seedlings originated from the same seed zone or within $\pm 200 \mathrm{~m}$ of altitude from the elevation of the reforestation site.

\section{Acknowledgements}

Funding was provided by the Mexican Council of Science and Technology (CONACYT), and the Mexican Forestry National Commission (CONAFOR) by grant 2002-C01-4655, and by the Coordinación de la Investigación Científica, Universidad Michoacana de San Nicolás de Hidalgo (UMSNH), grant 5.1 to CSR. We thank Consultores en Ecología y Manejo Sustentable for support with seed collection to Miguel A. Silva-FARÍAS and SELENE Aguilar-Aguilar and other students of Biology School, UMSNH, and CÉSAR CHÁVEZ-HERNÁNDEZ, INIRENAUMSNH, for test establishment and maintenance. Comments by JERRY REHFELDT and BRAD ST.ClAIR helped to significantly improve the manuscript.

\section{References}

Aitken, S. N., W. T. Adams, N. Schermann and L. H. FuchigAmi (1996): Family variation for fall cold hardiness in two Washington populations of coastal Douglasfir (Pseudotsuga menziesii var. menziesii (Mirb.) Franco). For. Ecol. Manage. 80: 187-195.

Aitken, S. N. and W. T. ADAMS (1997): Spring cold hardiness of under strong genetic control in Oregon populations of coastal Douglas-fir. Can. J. For. Res. 27: 1773-1780. 
ANEKONDA, T. S. and W. T. ADAMs (2000): Cold hardiness testing for Douglas-fir tree improvement programs: guidelines for a simple, robust and inexpensive screening methos. Western Journal of Applied Forestry. 15(3): $129-136$.

Bello-Lara, A. and J. Cibrián-Tovar (2000): Evaluación técnica de la reforestación 1998. In: Proceedings of the 1er. Congreso Nacional de Reforestación. Montecillo, Texcoco, México.

Binder, W. D., P. Fielder, G. H. Mohammed and S. J. L'HiRONDELLE (1997): Applications of chlorophyll fluorescence for stock quality assessment with different types of fluorometers. New For. 13: 63-89.

CAMPBELL, R. K (1979): Genecology of Douglas-fir in a watershed in the Oregon Cascades. Ecology 60: 1036-1050.

FARJON, A. and B. T. Styles (1997): Pinus (Pinaceae). Flora Neotropica. Monograph 75. New York Botanical Garden, New York.

GARCÍA, E. (1988): Modificaciones al sistema de clasificación climática de Köppen. UNAM, México D.F., 217 p.

MusÁlem, M. A. and O. SÁNCHez-CRUZ (2003): Monografía de Pinus michoacana Martínez. SAGARPA-INIFAPCONABIO, Chapingo, México.

PERRY, J. P. (1991): The pines of México and Central America. Timber Press, Portland Oregon, $231 \mathrm{p}$.

O’NeILL, G. A. (1999): Genetics of fall, winter and spring cold hardiness in coastal Douglas-fir seedlings. Ph.D. Dissertation. Oregon State University, Corvallis, Oregon.

REHFELDT, G. E. (1980): Cold acclimation in populations of Pinus contorta from the northern Rocky Mountains. Bot. Gazette. 141: 458-463.

REHFELDT, G. E. (1983a): Seed Transfer guidelines for Douglas-fir in western Montana. USDA For. Serv. Res. Note INT-329.

REHFELDT, G. E. (1983b): Seed Transfer guidelines for Douglas-fir in Central Idaho. USDA For. Serv. Res. Note INT-337.

REHFELDT, G. E. (1985): Ecological genetics of Pinus contorta in the lower Snake River Basin of central Idaho. USDA For. Serv. Res. Pap. INT-354.

REHFELDT, G. E. (1988): Ecological genetics of Pinus contorta from the Rocky Mountains (USA): a synthesis. Silv. Genet. 37: 131-135.
REHFELDT, G. E. (1989): Ecological adaptations in Douglas-fir (Pseudotsuga menziesii var. glauca): a synthesis. For. Ecol. Manage. 28: 203-215.

REHFELDT, G. E. (1991): A model of genetic variation for Pinus ponderosa in the Inland Northwest (USA): applications in gene resource management. Can. J. For. Res. 21: 1491-1500.

RosenBerb, N. J. (1974): Microclimate: the biological environment. Wiley and Sons, New York.

SÁENZ-Romero, C. (2004a): Zonificación estatal y altitudinal para la colecta y movimiento de semillas de coníferas en México. In: VARGAS-HeRnández, J. J., BERMEJoVELÁZquez, B. and LeDiG, F. T. (Eds.). Manejo de Recursos Genéticos Forestales. CONAFOR-Comisión Forestal de América del Norte, México. pp. 72-86.

SÁenZ-Romero, C. (2004b): Zonificación y conservación de coníferas en México. In: Vera C., G., VARGAs H. J. and DoRANTES L. J. (Ed.). Uso y Conservación de Recursos Genéticos Forestales. Comisión Nacional Forestal, México. pp. 21-28.

SÁenz-Romero, C., A. Snively and R. Lindig-Cisneros (2003): Conservation and restoration of pine forest genetic resources in México. Silv. Genet. 52(5-6): 233-237.

SÁenz-Romero, C. and R. Lindig-Cisneros (2004): Evaluación y propuestas para el programa de reforestación en Michoacán, México. Ciencia Nicolaíta 37: 107-122.

Sáenz-Romero, C., R. R. Guzmán-Reyna and G. E. ReHFELDT (2006): Altitudinal genetic variation among Pinus oocarpa populations in Michoacán, México; implications for seed zoning, conservation of forest genetic resources, tree breeding and global warming. For. Ecol. Manage. 229: 340-350.

SAS INSTITUTE INC. (1988): SAS/STAT Guide for personal computers. Version 6.03. SAS Institute Inc., Raleigh, North Carolina, USA.

SHORTT, R. L., B. J. HAwkins and J. H. Woods (1996): Inbreeding effects of the spring frost hardiness coastal Douglas-fir. Can. J. For. Res. 26: 1049-1054.

St.ClAIR, J. B. (2006): Genetic variation in fall cold hardiness in coastal Douglas-fir in western Oregon and Washington. Can. J. Bot. 84: 1110-1121.

\title{
Evaluation of Provenances of Eucalyptus camaldulensis and Clones of E. camaldulensis and E. tereticornis at Contrasting Sites in Southern India
}

\author{
By M. VARGHeSE ${ }^{1)}$, C. E. HARWood ${ }^{2)}$, R. HeGdE $^{1)}$ and N. Ravi ${ }^{1)}$
}

(Received 22 $2^{\text {th }}$ January 2007)

\begin{abstract}
A total of 188 open-pollinated families of Eucalyptus camaldulensis Dehnh. from 18 Australian natural

\footnotetext{
$\left.{ }^{1}\right)$ Institute of Forest Genetics and Tree Breeding (IFGTB), Coimbatore - 641002, India. Email: mvarghese1@rediffmail.com

2) CSIRO Sustainable Ecosystems, Private Bag 12, Hobart 7001, Australia.
}

provenances and 15 selected Indian families of the "Mysore Gum" land race were evaluated in three provenance-family trials at contrasting sites in southern India. At two years of age, the fastest growth was recorded at the driest site in Tamil Nadu, where $E$. camaldulensis provenances from Queensland were superior to those from Northern Territory and Western Australia, and the Indian land race. Provenance differ- 